\title{
Postural Discomfort in Manual Operations of Forest Planting
}

\author{
Eduardo da Silva Lopes ${ }^{1}$ (D), Pedro Caldas Britto ${ }^{1}$ (D), \\ Carla Krulikowski Rodrigues ${ }^{1}$
}

${ }^{1}$ Universidade Estadual do Centro-Oeste - UNICENTRO, Irati/PR, Brasil

\begin{abstract}
This study evaluated the postural discomfort and health risks of workers in manual forest plantation operations of a company located in the region of Campos Gerais, Paraná State. Data was collected through interviews, using the postural diagram proposed by Corlett, in a sample of 226 workers from manual planting, fertilization and herbicide application operations. The results indicated that manual planting operations caused greater postural discomfort in the legs of $56 \%$ of workers, while the fertilization and herbicide application caused discomfort in the shoulders of $41 \%$ and $56 \%$ of workers, respectively. The perception of postural discomfort during work is important to assist managers in adopting ergonomic measures for improving the safety and health of workers.
\end{abstract}

Keywords: silvicultural operations, postural diagram, ergonomics. 


\section{INTRODUCTION}

Forest implantation activities by manual and semi-mechanized methods involve a large amount of labor, especially when carried out on rough terrain. These activities are characterized by engaging the arms, legs and torso muscular strength, as well as by inappropriate postures, and handling of loads above the tolerable limits during the working day (Toupin et al., 2007; Silva et al., 2007). Such situations may cause discomfort, increase the risk of accidents and damage workers' health.

Adoption of static, cyclic and overloaded postures is a common situation in forest implantation activities, which may cause health risks to the vertebral osteoarticular system, joint wear and compromise the worker's physical integrity. Actually, the musculoskeletal disorders are the most frequent occupational health problem and significant economic costs for society (Grzywiński et al., 2016). Therefore, Kisner \& Colby (2009) and Silva et al. (2007) claim that when the worker maintains a posture with forceful application for a long period of time, there is a high risk of physical overload, leading to serious consequences to their health.

Discomfort and pain are health risk indicators, and can be used to detect possible problems in the human body Iida \& Guimarães (2016). They are warning signs for future health problems and indicators for taking mitigating measures. In case the work requirements are very severe and the adopted postures are inadequate, the pain may be persistent with progressive increase, and over time the muscles may change their consistency, becoming more tense and presenting thickening or painful nodules with a reduction in its natural movement.

Silva (2003) states that the use of questionnaires applied to workers in the form of interviews has been an efficient method for evaluating postural discomfort, as its parameters are not available in direct measurements. Assessment of postural discomfort can be obtained using a body map, where the worker reports the specific part (s) of the body with the highest incidence of discomfort, as well as its intensity and the occurrence period.

The postural discomfort map developed by Corlett (1995) is a psychophysical assessment technique that aims to map the presence of discomfort or pain perceived by workers. In this evaluation, workers mark the level of discomfort on a personal scale according to the subdivision of the existing body segments into a pre-elaborated human figure.

Some authors report that the evaluation of postural discomfort proposed by Corlett (1995) is an efficient method, able to efficiently and quickly detect postural problems in workers, with great application in activities performed by manual, semi-mechanized or mechanized methods. In evaluating manual planting in upland areas in New Zealand, Sullman \& Byers (2000) found that approximately half of the workers presented postural discomfort, with greater occurrence in the elbows, backs and lower back. Pauluk \& Michaloski (2016) applied the method to workers performing tillage activity with an agricultural tractor, and identified discomfort occurring in regions of the legs, thighs and neck in the majority of the interviewees.

Therefore, the importance of ergonomically evaluating work through identifying the occurrence of postural discomfort can be emphasized. This allows forest managers to ergonomically reorganize the work and introduce new equipment, tools and work techniques with consequent improvement to the safety and health conditions of workers.

This study aimed to evaluate the postural discomfort in workers during the execution of forest implantation manual activities, contributing with information for the ergonomic reorganization of the work and improving the conditions of well-being, comfort, safety and health for the workers.

\section{MATERIAL AND METHODS}

The study was carried out in a company located in the region of Campos Gerais, Parana State, in implantation activities of Pinus spp. stands. The predominant climate of the region is characterized as subtropical (Cfa), according to the Köppen classification, with average temperature ranging from $18^{\circ}$ to $22^{\circ} \mathrm{C}$ in the colder and hotter months, respectively; hot summers, infrequent frosts and tendency of rain concentration during the summer months. The relief of the studied area was characterized as strongly undulated, with slopes varying from $20 \%$ to $45 \%$.

We studied planting, fertilization and herbicide application activities performed manually. For planting, the workers used a set consisting of a tubular planter 
connected to a costal sprayer or hydrogel storage. The equipment had a total mass of $28.9 \mathrm{~kg} ; 4.5 \mathrm{~kg}$ of planter, $19.8 \mathrm{~kg}$ of costal sprayer costal sprayer with hydrogel and $4.6 \mathrm{~kg}$ of seed box, both supplied. For fertilization, the workers used a set consisting of a "ratchet" fertilizer connected to a costal sprayer for storing the fertilizer with a total mass of $20.3 \mathrm{~kg}$, being $4.1 \mathrm{~kg}$ of fertilizer mass and $16.2 \mathrm{~kg}$ of fertilizer mass of the costal sprayer supplied with fertilizer. For herbicide application, they used a costal sprayer with a mass of $19.0 \mathrm{~kg}$, connected to a sprinkler equipped with protection called a "Napoleon hat" (Figure 1).

The evaluated population consisted of 226 forest workers, from which 62 worked in planting activities,
64 in fertilization and 100 in herbicide application. The characteristics of the studied workers are presented in Table 1.

All participating workers initially received clarifications about the methodology and objectives of the research by reading and signing the Informed Consent Form (ICF), as required by Resolution $\mathrm{N}^{\circ} 196 / 96$ of CONEP (National Commission on Ethics in Research) of the Ministry of Health (Brasil, 2012).

Evaluation of postural discomfort was performed through an individual questionnaire applied to the workers in the form of an interview in the workplace. We used the methodology proposed by Corlett (1995), which consisted of a body map in the form
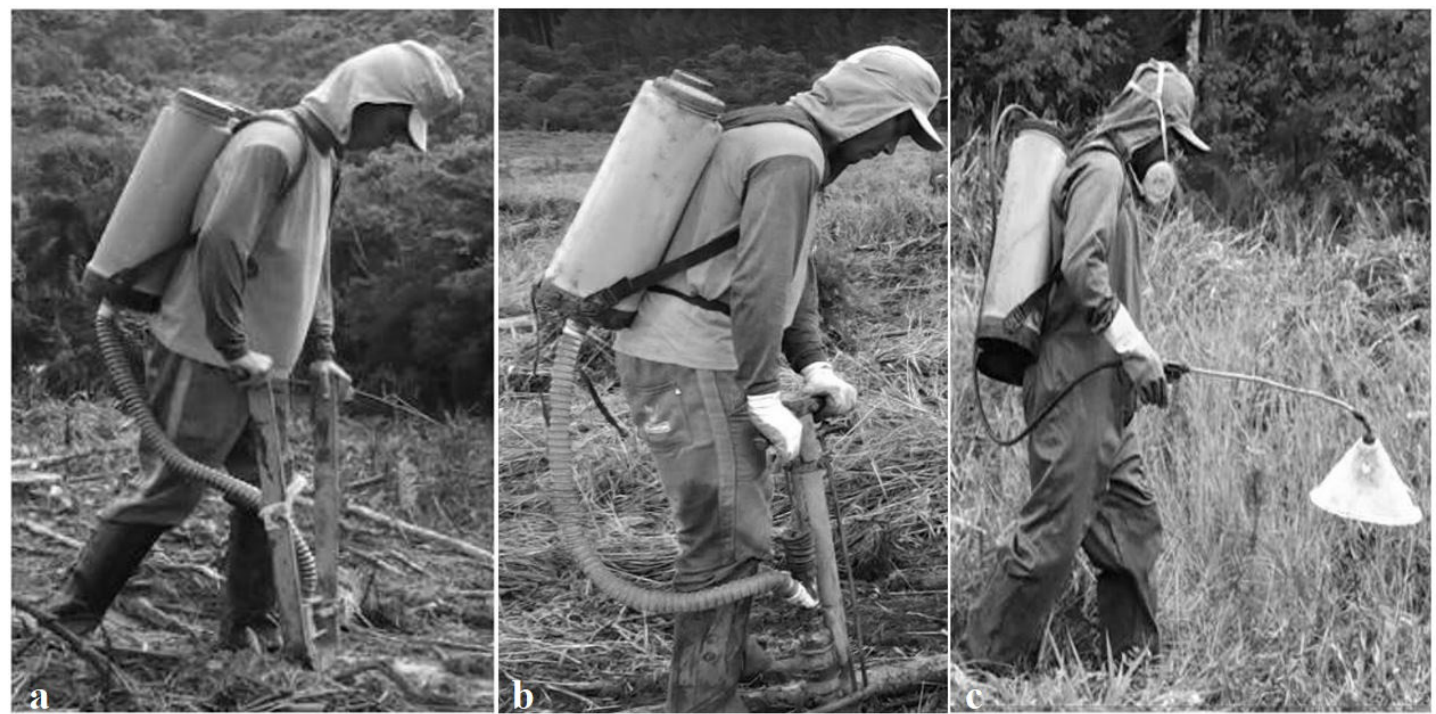

Figure 1. Evaluated forest planting operations. (a) Planting; (b) Fertilization; (c) Herbicide application.

Table 1. Characterization of the evaluated workers in forest planting operations.

\begin{tabular}{|lcccc}
\hline \multicolumn{2}{c}{ Characteristics } & Planting & Fertilizing & $\begin{array}{c}\text { Herbicide } \\
\text { application }\end{array}$ \\
\hline \multirow{3}{*}{ Body mass (kg) } & Average & 70.5 & 68.1 & 70.8 \\
& Minimum & 49.8 & 48.4 & 48.1 \\
& Maximum & 101.1 & 96.2 & 98.3 \\
\multirow{2}{*}{ Stature (m) } & Average & 1.68 & 1.68 & 1.68 \\
& Minimum & 1.56 & 1.52 & 1.51 \\
\hline \multirow{3}{*}{ Age (years) } & Maximum & 1.84 & 1.80 & 3.80 \\
& Average & 36 & 36 & 19 \\
\hline \multirow{2}{*}{$\begin{array}{l}\text { Functional } \\
\text { experience (month) }\end{array}$} & Minimum & 21 & 19 & 57 \\
\hline & Maximum & 57 & 55 & 42 \\
\hline
\end{tabular}


of a pre-elaborated human figure, called the Postural Diagram (Figure 2).

The body map subdivided the human body into 28 parts, being: Neck (0); Cervical region (1); Upper back (2); Middle back (3); Lower back (4); Hip (5); Left Shoulder (6); Right Shoulder (7); Left Arm (8); Right Arm (9); Left elbow (10); Right Elbow (11); Left Forearm (12); Right forearm (13); Left Wrist (14); Right Wrist (15); Left Hand (16); Right Hand (17); Left thigh (18); Left Leg (20,22,24,26); Right Thigh (19); and Right Leg $(21,23,25,27)$.

During the interviews, the workers identified the parts of their body with the greatest postural discomfort caused by the performed activities in the diagram, subjectively reporting the intensity on a numerical scale from 1 to 5 (Table 2), the location and the frequency of postural discomfort occurrence.

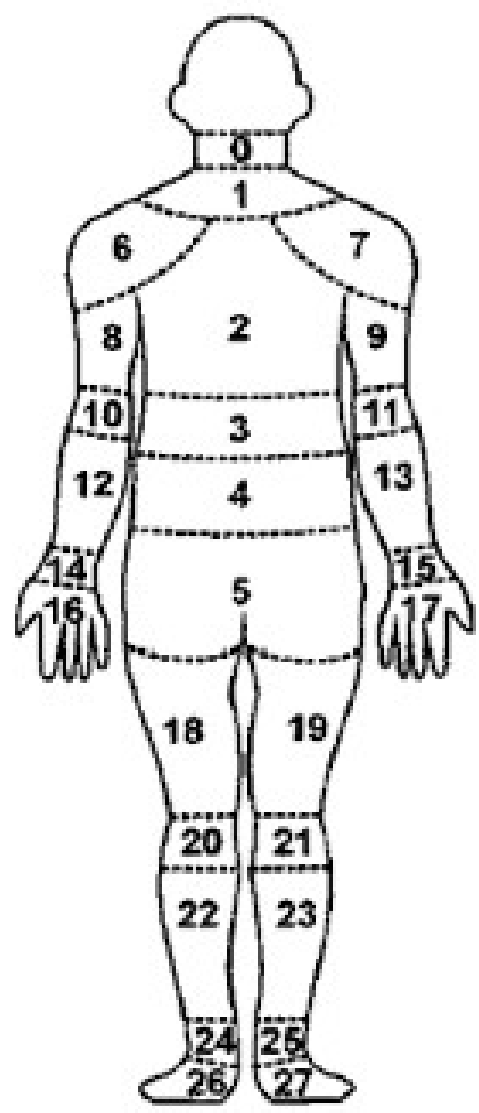

Figure 2. Diagram used in evaluation of postural discomfort of workers. Source: Adapted from Corlett (1995)
Regarding the location, the workers were questioned whether the postural discomfort caused by the work occurred only during work, after work in their residences or in both situation, in order to verify if the intensity was damaging the daily lives of the workers. Regarding the frequency, the workers were asked if the discomfort and pain were of rare, sporadic or frequent occurrence.

The questionnaires were analyzed by coding and typing the data into a spreadsheet, and creation of a database. Next, we performed a descriptive statistical analysis.

\section{RESULTS AND DISCUSSION}

The workers' perception of the postural discomfort caused by the forest implantation activities is illustrated in Figure 3 as a percentage for the various body segments. Plantation was the forest implantation activity that caused the greatest discomfort to the workers, affecting their upper backs (56\%), shoulders (34\%), lower back (32\%) and wrists (23\%).

In herbicide application, worker reports discomfort predominantly in the shoulders (56\%), legs (54\%) and lower back (28\%). On the other hand, the fertilization activity presented a smaller number of workers' postural discomfort claims, being mainly in the shoulders (45\%) and in the legs (36\%).

In general, the legs were most mentioned as postural discomfort in the three evaluated forest implantation activities. According to Vosniak et al. (2011), in carrying out a biomechanical evaluation of workers in silvicultural activities, the occurrence of discomfort in the legs can be attributed to the workers' need to travel long distances during the working day, a common situation in silvicultural activities; in addition to the challenges within the areas themselves due to slope, presence of residues and obstacles.

Table 2. Intensity scale of postural discomfort.

\begin{tabular}{cc|}
\hline Intensity & Description \\
\hline 1 & No discomfort \\
2 & Some discomfort \\
3 & Moderate discomfort \\
4 & Enough discomfort \\
5 & Intolerable discomfort \\
\hline
\end{tabular}

Source: Adapted from Corlett (1995). 

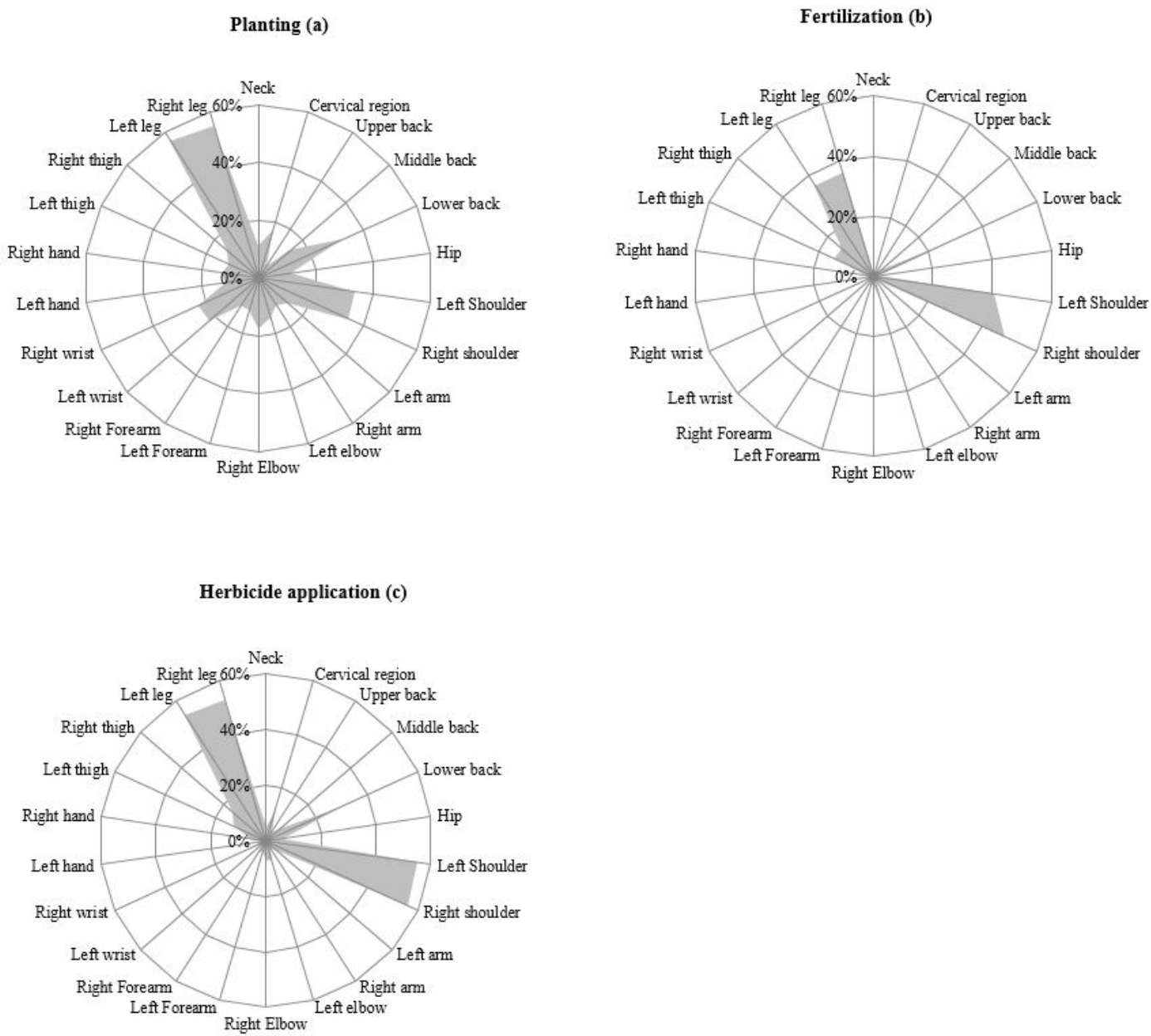

Figure 3. Workers' perception of postural discomfort in the evaluated operations: (a) Planting; (b) Fertilization; (c) Herbicide application.

Other regions of the human body pointed out by the workers as sites of postural discomfort were shoulders (in all evaluated activities), and wrists/hands (in the planting activity). The occurrence of shoulder discomfort may be related to the weight of the costal sprayer for hydrogel storage, together with adopting inadequate postures when performing the work. While the discomfort in the wrists can be attributed to the frequent vertical movements performed in triggering the planter at the time of planting.

It is important to emphasize that the weight handled by the workers during the displacement between the place of supply and the field, especially at the beginning of planting when there is a greater weight, can be a factor causing the workers' postural discomfort. In addition, Britto et al. (2014) emphasize the need to adjust the equipment in order to improve the posture adopted by the workers when performing silvicultural activities, mainly because the activity is cyclical, meaning that the inadequate postures are repeatedly adopted by the workers during work, and may cause serious future health damage.

Therefore, the need to adopt measures to improve working conditions is evident, such as ergonomic work reorganization by means of better distribution of the seedlings within the field, consequently reducing the number of workers' and the amount of hydrogel inserted in the costal sprayer.

Fertilization was the activity with the lowest report of postural discomfort, presenting few complaints of 
discomfort in the shoulder and leg regions. This result is in agreement with Fiedler et al. (2011), who analyzed the postures adopted in the manual fertilization operation, and verified that there was no need for corrective measures. However, for situations where there has been discomfort, it can be justified by the heavy weight of the costal sprayer with the fertilizer, which together with the high path taken by workers to work may have contributed to the occurrence of greater postural discomfort.

Another issue that may justify workers postural discomfort in the planting and fertilization activities is the lack of service of the forest tools to the anthropometry of the workers. According to Lopes et al. (2013), the planter and the fertilizer do not meet the anthropometry of forest workers in the 95 percentile in the height of the tool, causing a slope in the spine, especially in taller workers; in the length of the handle, damaging work performance; and in the maximum and minimum rod opening, where the width of the workers 'shoulders must be respected so that there is no excessive opening of the arms which causes discomfort and compromises the workers' health.

Regarding the herbicide application activity, the greatest discomforts occurred in the shoulder and leg regions, in addition to the lower back, which could be related to the heavy weight of the costal sprayer and the long distances traveled by the workers during the working day. In addition, discomfort in the lower back reported by the interviewees can be attributed to the direct contact of the costal sprayer with this region of the body, in which case ergonomic measures should be adopted such as designing a costal sprayer that best suits different body types of the workers.

According to a study by Lopes et al. (2011), the herbicide application activity can be classified as moderately heavy, and workers are advised to perform recovery breaks throughout the working day, allowing for rest and muscle relaxation. This recommendation is important because it is an activity performed by the workers in a standing position during the whole working day, a highly stressful situation that requires static work of the involved musculature to maintain such position.

Figure 4 shows the intensity of postural discomfort in the regions of the body where there were the greatest complaints from workers (shoulders and legs). As can be seen in most of the evaluated activities, most reports of postural discomfort in workers' perception were considered in class 2 , meaning with some discomfort occurring, and it should also be noted that there were no reports of intolerable discomfort.

In the planting activity, the highest intensity of discomfort in the perception of $28 \%$ of workers occurred in classes 3 and 4 (moderate and strong discomfort), respectively, with the legs indicated as the region of the body most compromised. This result of discomfort intensity in the legs was also verified by Sullman \& Byers (2000), who attributed this discomfort to the slope of the terrain, a situation that increases the demands of workers' feet, ankles and legs during work.

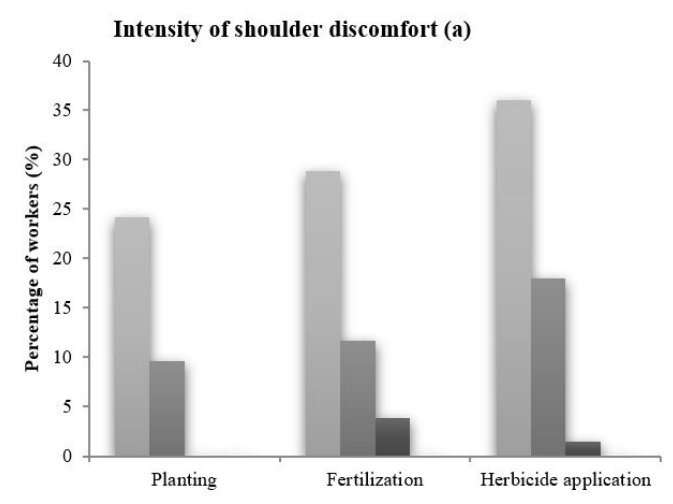

- Some discomfort

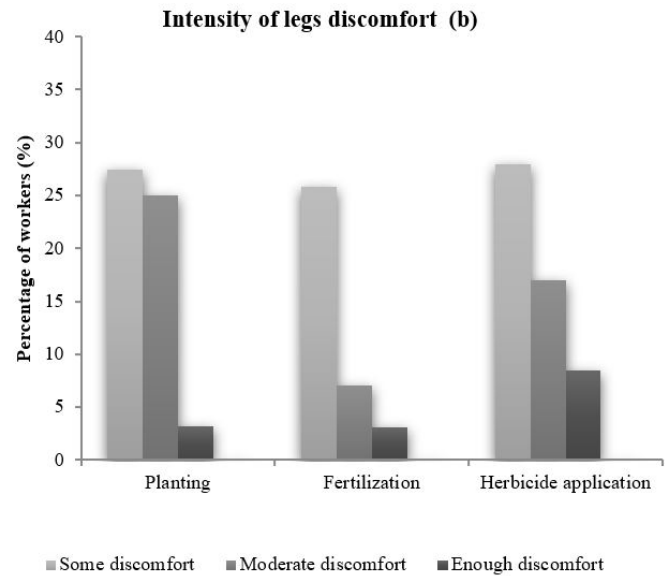

Figure 4. Intensity of workers postural discomfort in the regions of the shoulders (a) and legs (b). 
Table 3. Percentage distribution of the occurrence frequency and location of postural discomfort.

\begin{tabular}{|c|c|c|c|c|c|c|}
\hline \multirow[b]{2}{*}{ Operation } & \multicolumn{3}{|c|}{ Frequency of occurrence } & \multicolumn{3}{|c|}{ Place of occurrence } \\
\hline & $\begin{array}{c}\text { Rare } \\
(\%)\end{array}$ & $\begin{array}{c}\text { Sporadic } \\
\text { (\%) }\end{array}$ & $\begin{array}{c}\text { Always } \\
(\%)\end{array}$ & $\begin{array}{l}\text { At work } \\
(\%)\end{array}$ & $\begin{array}{c}\text { At home } \\
(\%)\end{array}$ & $\begin{array}{c}\text { Both sites } \\
\text { (\%) }\end{array}$ \\
\hline Planting & 24 & 34 & 42 & 88 & 8 & 4 \\
\hline Fertilizing & 17 & 23 & 55 & 70 & 1 & 25 \\
\hline Herbicide application & 7 & 40 & 53 & 88 & 1 & 12 \\
\hline
\end{tabular}

Fertilization was the activity that presented the lowest discomfort intensity for 8 and $7 \%$ of workers, located in the shoulder and leg regions, respectively. Regarding the herbicide application, there was a greater discomfort in the leg region (26\%) and shoulders (20\%), classified with intensity of 3 and 4 , meaning moderate and strong discomfort, respectively. This result evidenced the greater involvement of the shoulder region of the workers in performing this activity, and it can be attributed to the weight and shape of the costal sprayer, which did not fit the workers' body perfectly, thus causing greater discomfort in conducting their work.

For Fernandes et al. (2008), the shoulders are usually compromised due to repetitive movements for long periods of time, being characteristic in occupational activities and may cause inflammation of the synovial sacs and provoke pain symptoms.

When asked about the frequency and site of postural discomfort, the majority reported feeling it during work (Table 3). Regarding the percentage of workers in the fertilization activity (25\%) that said they felt discomfort at work and in their homes, it was evident that this situation is worrisome and in the long run could cause harm to the health and quality of life of workers.

It is important to note that regardless of the frequency of occurrence of postural discomfort being considered rare or sporadic, the results showed the existence of ergonomic problems in manually performing forest implantation activities, and therefore ergonomic measures should be adopted for improving the conditions of comfort, health and safety of forestry workers.

\section{CONCLUSIONS}

The equipment weight and the long distance traveled were pointed out by the workers as being the causes of greater postural discomfort in the shoulder and leg regions during forestry implantation activities.
From the workers' perception, planting was the activity with the majority of postural discomfort reports, with such ergonomic problems occurring during work execution.

The identification of postural discomfort is important to assist managers in adopting ergonomic measures aimed at improving safety and health conditions, especially in forest implantation, since its activities are cyclical and requires the workers to stand during the working day.

\section{ACKNOWLEDGEMENTS}

The authors acknowledge the forestry company by support for this research.

\section{SUBMISSION STATUS}

Received: 18 jan., 2017

Accepted: 25 jan., 2018

\section{CORRESPONDENCE TO}

\section{Eduardo da Silva Lopes}

Universidade Estadual do Centro-Oeste UNICENTRO, Rodovia PR 153, Km 7, Bairro Riozinho, CEP 84500-000, Irati, PR, Brasil e-mail: eslopes@unicentro.br

\section{FINANCIAL SUPPORT}

Nothing to declare.

\section{REFERENCES}

Brasil. Conselho Nacional de Saúde - CNS. Resolução no 466, de 12 de dezembro de 2012 [online]. Diário Oficial da República Federativa do Brasil, Brasília, DF (2012 dez.) [cited 2013 July 20]. Available from: http://conselho.saude. gov.br/resolucoes/2012/Reso466.pdf 
Britto PC, Lopes ES, Laat EF, Fiedler NC. Avaliação biomecânica de trabalhadores de diferentes estaturas nas atividades de plantio e adubação florestal. Scientia Forestalis 2014; 42(102): 191-196.

Corlett EN. The evaluation of posture and its effects. In: Wilson JR, Corlett EN, editors. Evaluation of human work: a practical ergonomics methodology. London: Taylor \& Francis; 1995.

Fernandes HAN, Minette LJ, Juvêncio JF, Silva EP, Souza AP, Diniz CS. Fatores de risco para distúrbios osteomusculares nos ombros de trabalhadores envolvidos na colheita de café. Engenharia na Agricultura 2008; 16(3): 318-328. http://dx.doi.org/10.13083/1414-3984.v16n03a06.

Fiedler NC, Barbosa RP, Andreon BC, Gonçalves SB, Silva EN. Avaliação das posturas adotadas em operações florestais em áreas. Floresta e Ambiente 2011; 18(4): 402409. http://dx.doi.org/10.4322/floram.2011.059.

Grzywiński W, Wandycz A, Tomczak A, Jelonek T. The prevalence of self-reported musculoskeletal symptoms among loggers in Poland. International Journal of Industrial Ergonomics 2016; 52: 12-17. http://dx.doi.org/10.1016/j. ergon.2015.07.003.

Iida I, Guimarães LBM. Ergonomia: projeto e produção. 3. ed. São Paulo: Edgard Blücher; 2016.

Kisner C, Colby LA. Exercícios terapêuticos: fundamentos e técnicas. 5. ed. São Paulo: Manole; 2009.

Lopes ES, Britto PC, Laat EF, Fiedler NC, Vieira TP. Análise antropométrica de trabalhadores em atividades de implantação florestal. Floresta 2013; 43(4): 525-534. http://dx.doi.org/10.5380/rf.v43i4.32612.

Lopes ES, Oliveira FM, Rodrigues CK. Determinação da carga física de trabalho na atividade de aplicação manual de herbicida. Ambiência 2011; 7(2): 329-337. http://dx.doi. org/10.5777/ambiencia.2011.02.10.

Pauluk D, Michaloski AO. Análise ergonômica do trabalho nas atividades de preparo do solo com trator agrícola. Espacios 2016; 37(4): 24.

Silva EM. Avaliação da preferência de cadeiras para diferentes tipos de trabalhos de escritório [dissertação]. Porto Alegre: Universidade Federal do Rio Grande do Sul; 2003.

Silva EP, Minette LJ, Souza AP. Análise ergonômica do trabalho de coveamento semimecanizado para o plantio de eucalipto. Scientia Forestalis 2007; 76(4): 77-83.

Sullman MJM, Byers J. An ergonomic assessment of manual planting Pinus Radiata Seedlings. International Journal of Forest Engineering 2000; 11(1): 51-58.

Toupin D, LeBel L, Dubeau D, Imbeau D, Bouthillier L. Measuring the productivity and physical workload of brushcutters within the context of a production-based pay system. Forest Policy and Economics 2007; 9(8): 1046-1055. http://dx.doi.org/10.1016/j.forpol.2006.10.001.

Vosniak J, Lopes ES, Inoue MT, Batista A. Avaliação da postura de trabalhadores nas atividades de plantio e adubação em florestas plantadas. Revista Ceres 2011; 58(5): 584-592. http://dx.doi.org/10.1590/S0034-737X2011000500008. 